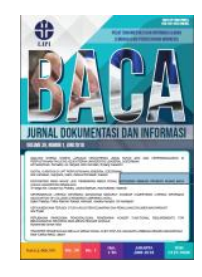

\title{
TRANSFER PENGETAHUAN PENGAJAR TUNANETRA DI YAYASAN MITRA NETRA
}

\author{
Risqi Putri Wulandari ${ }^{1 *}$; Kiki Fauziah ${ }^{2}$ \\ ${ }^{1,2}$ Program Studi Ilmu Perpustakaan, Fakultas Ilmu Budaya \\ Universitas Indonesia \\ ${ }^{1}$ Korespondensi: risqi.putri@ui.ac.id
}

Diajukan: 13-01-2020; Direview: 28-06-2020; Diterima: 17-07-2020; Direvisi: 01-09-2020

\begin{abstract}
This paper discusses the process of transferring knowledge blind educators in Yayasan Mitra Netra. The aim of this research is to explain the process of transferring knowledge blind educators and also to find out the obstacle in process of transferring knowledge blind educators in Yayasan Mitra Netra. This paper used a qualitative approach with study case method. Data collection techniques in this research used interview, observation, and document analysis. This research found that transferring knowledge blind educators in Yayasan Mitra Netra is to develop student's knowledge and skills. Yayasan Mitra Netra is informal education institution with the majority of student in Yayasan Mitra Netra are adult students who will go on to college and work. Collaboration between teachers and students who feel that they have something in common makes the knowledge transfer process effective. The seci process in socialization phase is most prominent compared to the other phase, because teachers and students are blind who have lack in seeing and making them only rely on the other senses such as hearing, touch, taste, and etc. in receiving knowledge. So, tacit knowledge can be created and transferred well, although that there are many obstacles in process of transferring knowledge blind educators are laziness, mood, teach too fast, and blind with other needs.
\end{abstract}

\begin{abstract}
ABSTRAK
Penelitian ini membahas tentang proses transfer pengetahuan pengajar tunanetra di Yayasan Mitra Netra. Tujuan penelitian ini untuk mengidentifikasi proses transfer pengetahuan dan hambatan dalam proses transfer pengetahuan pengajar tunanetra di Yayasan Mitra Netra. Penelitian ini menggunakan pendekatan kualitatif dengan metode studi kasus. Teknik pengumpulan data pada penelitian ini menggunakan wawancara, observasi, dan analisis dokumen. Hasil penelitian ini menunjukan bahwa sosialisasi paling dominan dibandingkan tahap lainnya, karena pengajar maupun murid merupakan penyandang tunanetra yang memiliki kekurangan dalam indera penglihatan dan membuat mereka hanya mengandalkan indera lainnya seperti pendengaran, peraba, pengecap, dan sebagainya dalam menerima pengetahuan. Ibaratkan seseorang dengan penglihatan normal menutup matanya dan harus menebak jenis buah di depannya, mereka menjawab dengan mengandalkan pengetahuan tasit yang ada dalam diri mereka. Itulah tunanetra walaupun kekurangan dalam indera penglihatan tetapi mereka memiliki kepekaan yang lebih pada indera lainnya seperti penciuman, pendengaran, peraba, dan pengecap, sehingga dalam transfer pengetahuan, pengetahuan tasit tercipta dan tertransfer dengan baik. Walaupun begitu, terdapat hambatan yang dihadapi yaitu sifat malas, suasana hati, mengajar terlalu cepat, dan tunanetra yang mempunyai kebutuhan lain.
\end{abstract}

Keywords: Knowledge transfer; Educators; Learning process; Organization; Difable user; Mitra Netra

\section{PENDAHULUAN}

Dalam kehidupan sehari-hari, informasi mempunyai peran penting. Salah satunya adalah memberikan dan memperluas pengetahuan manusia. Informasi yang ada diolah menjadi suatu pengetahuan. Menurut Tobing (2007), pengetahuan sebagai informasi yang mengubah sesuatu atau seseorang, terjadi ketika informasi menjadi dasar seseorang dalam bertindak, atau ketika informasi tersebut memampukan seseorang atau institusi untuk mengambil tindakan yang berbeda atau tindakan yang lebih efektif dari tindakan sebelumnya. Pengetahuan dibedakan menjadi dua yaitu tasit dan eksplisit. Pengetahuan tasit merupakan pengetahuan yang ada dalam otak atau melekat dalam diri seseorang yang diperolehnya melalui pengalaman dan pekerjaannya, sedangkan pengetahuan eksplisit adalah pengetahuan dengan segala bentuk yang sudah direkam, dan didokumentasikan, sehingga lebih mudah didistribusikan dan dikelola. Pengetahuan tasit 
diubah menjadi pengetahuan eksplisit agar dapat diterima lebih mudah oleh pihak lainnya. Proses ini dinamakan transfer pengetahuan. Transfer pengetahuan dilakukan dengan berbagai cara, seperti percakapan tatap muka, mengikuti forum, seminar, rapat, maupun pembelajaran dalam kelas. Transfer pengetahuan yang efektif sangatlah penting karena dapat mengurangi biaya pengeluaran organisasi dan waktu dalam pelatihan dan juga memberikan kebebasan akses dan waktu yang fleksibel untuk anggota yang ada dalam organisasi tersebut.

Transfer pengetahuan berfungsi sebagai pencapai tujuan dalam suatu organisasi karena ketika pengetahuan hanyalah informasi yang ada dalam suatu database di diri seseorang, maka organisasi tidak dapat menggunakan pengetahuan tersebut. Transfer pengetahuan bukanlah suatu yang sederhana tetapi juga mempertimbangkan banyaknya faktor yang ada (Liyanage, 2009). Transfer pengetahuan terjadi pada seluruh lapisan masyarakat tanpa memandang suku, agama, ras, jenis kelamin, umur, maupun fisik termasuk penyandang tunanetra. Tunanetra memiliki keterbatasan fisik dalam penglihatan. Tunanetra mengalami kurangnya pengalaman dalam bentuk visual dalam mengamati orang lain, dan juga kurang dalam bersosialisasi dengan orang lain. Proses transfer pengetahuan akan dilakukan dengan pengajar sebagai pemilik dan pengirim pengetahuan. Pengajar mentransfer pengetahuan dan keterampilan yang mereka miliki kepada para murid. Transfer pengetahuan yang dilakukan oleh para pengajar kepada murid akan menghasilkan suatu pengetahuan baru yang dapat mereka terapkan dalam kehidupan mereka

Pada dasarnya transfer pengetahuan dalam sekolah bertujuan untuk inovasi dan perkembangan masyarakat yang berada di lingkungannya. Semakin sering pengetahuan ditransfer, semakin efektif pula proses transfer pengetahuan yang terjadi (Cabera-Suarez, 2001). Biasanya transfer pengetahuan yang dilakukan berada di sekolah maupun lembaga pendidikan informal untuk melakukan proses transfer pengetahuan, seperti Yayasan Mitra Netra yang merupakan lembaga informal untuk para tunanetra.

Penelitian sebelumnya yang ditulis oleh Laksmi, Wijayanti, \& Fauziah (2016) dengan judul "Local Wisdom-Based Strategy of Transferring Knowledge Among Educators at Early Childhood Education Programs In Srengseng Sawah Sub-District, Jagakarsa District, South Jakarta", membahas transfer pengetahuan yang terjadi di PAUD daerah Srengseh Sawah, Jagakarsa, dan Jakarta Selatan dengan pendekatan kearifan lokal oleh pengajarnya. Hasil penelitian menunjukkan bahwa transfer pengetahuan antar-pengajar dilakukan karena para pengajar tidak memiliki status sebagai pengajar formal di PAUD dan tidak memiliki latar belakang pendidikan PAUD. Sehingga mereka berinisiatif membangun hubungan sosial berdasarkan nilai egalitarian (percaya dan menghargai satu sama lain) dan cosmopolitan (keterbukaan, jujur, dan berorietasi dengan teknologi informasi). Penelitian lainnya ditulis oleh Chandra (2015) dengan judul "Pemanfaatan Media pada Tunanetra di Jakarta (Sebuah Studi tentang Pemanfaatan Media oleh Anggota Perpustakaan Yayasan Mitra Netra)", hasilnya menunjukkan bahwa tunanetra memiliki keinginan media yang tinggi meskipun menghadapi berbagai hambatan dalam penglihatan. Aksesbilitas yang mereka hadapi menjadikan mereka aktif dalam mencari solusi agar dapat menggunakan media.

Berdasarkan kedua penelitian diatas, peneliti ingin melihat gambaran tentang para pengajar kepada murid terutama pengajar tunanetra kepada muridnya. Penulis tertarik untuk mengkajinya secara mendalam tentang kegiatan transfer pengetahuan yang dilakukan oleh pengajar di Yayasan Mitra Netra. Permasalahan penelitian ini yaitu "bagaimana proses transfer pengetahuan pengajar tunanetra di Yayasan Mitra Netra?". Penelitian ini bertujuan untuk mengidentifikasi proses transfer pengetahuan dan hambatan dalam proses transfer pengetahuan pengajar tunanetra di Yayasan Mitra Netra sehingga dapat mengetahui proses transfer pengetahuan pengajar tunanetra. 


\section{TINJAUAN PUSTAKA}

\subsection{Pengetahuan}

Pengetahuan adalah suatu konsep kompleks yang menarik banyak filsuf, peneliti dari disiplin ilmu dan praktisi lainnya. Pengetahuan adalah lebih sekedar data dan informasi belaka. Data dianggap sebagai dasar untuk menciptakan informasi dan pengetahuan. Data merupakan serangkaian fakta dari suatu peristiwa. Mereka dipresentasikan dengan karakter dan bisa diproduksi, dikodifikasi, dan didistribusikan tanpa referensi ke konteks ataupun individu. Sedangkan menurut International Encylopedia of Information and Library Science (2003), informasi merupakan sekumpulan data yang diproses dalam bentuk yang memiliki arti dan mampu dipahami untuk komunikasi serta digunakan sebagai suatu fakta dimana sebuah arti melekat didalamnya. pesan atau berita yang dibuat dengan menginterpretasi data. Adapun pengetahuan muncul dari hasil proses informasi yang disadari dan terkonteks dalam seseorang. Pengetahuan memiliki konteks dan diciptakan dengan mengintegrasikan informasi dengan pengalaman, intuisi, dan penilaian (Warnar, 2012).

Pengetahuan merupakan informasi yang dapat mengubah seseorang maupun sesuatu dan terjadi ketika informasi dijadikan dasar dalam bertindak ataupun informasi dapat membuat sesorang atau organisasi dalam mengambil suatu tindakan yang lebih efektif (Drucker, 1988; Tobing, 2007). Menurut Awad \& Ghaziri (2010), pengetahuan adalah suatu pemahaman dan keyakinan manusia dalam bidang tertentu yang diminati dan diperoleh melalui pembelajaran. Sedangkan menurut Davenport \& Prusak (1998) dan Greiner et al., (2007), pengetahuan adalah campuran dari pengalaman, nilai-nilai, kontekstual, informasi, dan wawasan seseorang yang menyediakan suatu kerangka untuk mengevaluasi dan menggabungkan pengalaman dan informasi baru. Pengertian di atas dapat disimpulkan bahwa pengetahuan adalah suatu informasi campuran dari nilai, pengalaman, wawasan seseorang maupun kelompok dan menjadi suatu dasar dalam mengambil suatu tindakan yang efektif.

Pengetahun dibagi menjadi dua, yaitu pengetahuan tasit dan eksplisit. Pengetahuan tasit dan eksplisit merupakan salah satu dimensi dari transfer pengetahuan. Pengetahuan tasit memiliki suatu komponen sendiri, yang mana sulit untuk dirumuskan maupun dikomunikasi. Pengetahuan tasit merupakan pengetahuan yang berada di otak manusia dan tidak mudah untuk dikomunikasi (Wong \& Radcliffe, 2000). Pengetahuan tasit merupakan pengetahuan yang berada di dalam pikiran individu dan bersifat tidak terstruktur sehingga sulit dikomunikasikan. Adapun pengetahuan eksplisit bisa diubah dalam bahasa yang formal maupun sistematik, mudah untuk dikomunikasikan dan dibagikan dibandingkan pengetahuan tasit (Bou-Llusar \& Segarra-Cipres, 2006). Menurut Liyanage (2009), pengetahuan eksplisit adalah pengetahuan yang dapat dikomunikasikan dalam bahasa formal dan mudah di bagikan antar individu maupun kelompok. Tidak hanya itu pengetahuan eksplisit juga lebih dapat diekspresikan dan dibagikan dengan mudah. Beberapa peneliti berpendapat bahwa pengetahuan tasit lebih berharga daripada pengetahuan eksplisit dan sebaliknya. Walaupun begitu pengetahuan tasit merupakan pembentuk yang diperlukan dalam mengembangkan dan menafsirkan pengetahuan eksplisit maka dari itu keterkaitan antara pengetahuan tasit dan eksplicit tidak dapat dipisahkan.

\subsection{Transfer Pengetahuan}

Pengetahuan memiliki konteks dan diciptakan dengan mengintegrasikan informasi dengan pengalaman, intuisi, dan penilaian (Warnar, 2012). Menurut Awad \& Ghaziri (2010), pengetahuan adalah suatu pemahaman dan keyakinan manusia dalam bidang tertentu yang diminati dan diperoleh melalui pembelajaran. Pengetahuan dibagi menjadi dua jenis yaitu, 
pengetahuan tasit dan pengetahuan eksplisit. Pengetahuan tasit memiliki suatu komponen sendiri, yang mana sulit untuk dirumuskan maupun dikomunikasi. Pengetahuan tasit merupakan pengetahuan yang berada di dalam pikiran individu dan bersifat tidak terstruktur sehingga sulit dikomunikasikan. Adapun pengetahuan eksplisit bisa diubah dalam bahasa yang formal maupun sistematik, mudah untuk dikomunikasikan dan dibagikan dibandingkan pengetahuan tasit (BouLlusar \& Segarra-Cipres, 2006).

Transfer pengetahuan diartikan sebagai sebuah proses perubahan dari pengetahuan eksplisit atau tasit diantara dua agen, yang dimana salah satu agen menjadi penerima dan menggunakan pengetahuan yang telah disediakan. Agen yang dimaksud adalah individu, kelompok, unit organisasi, organisasi itu sendiri, atau kelompok organisasi itu sendiri (Kumar \& Ganesh, 2009). Liyanage et al. (2009) mengatakan bahwa transfer pengetahuan tidak hanya tentang pemanfaatan sumber daya yang dapat diakses tetapi juga tentang cara memperoleh dan menyerap pengetahuan dengan baik untuk membuat suatu hal menjadi lebih efektif dan efisien. Transfer pengetahuan dalam organisasi bisa didapatkan dengan beberapa cara, yaitu dengan interaksi antar individu, percakapan dan rapat, storytelling, personnel movement, pelatihan, observasi, dan publikasi dari paten dan artikel maupun jurnal sains (Jasimuddin et al., 2014).

Menurut Narteh (2008), ada beberapa faktor yang mendukung terjadinya transfer pengetahuan, yakni sebagai berikut.

1) Faktor pengirim pengetahuan. Faktor dalam pengirim pengetahuan yang mempengaruhi kemampuanya dalam mentransfer pengetahuan ke penerima pengetahuan. Faktor pengirim pengetahuan tersebut, yaitu:

(a) sifat pengetahuan, sifat dari pengetahuan yang akan ditransfer dapat berdampak dengan proses transfer pengetahuan, seperti pengetahuan tasit dan eksplisit.

(b) metode yang diadopsi, metode transfer pengetahuan yang efektif sesuai dengan metode yang mereka gunakan.

(c) kemampuan mengajar, kemampuan dalam mengajar adalah hal terpenting untuk pengirim pengetahuan. Semakin banyak pengalaman dalam mentransfer pengetahuan akan lebih mudah untuk mentransfer pengetahuan dalam pembelajaran.

2) Faktor penerima pengetahuan. Dalam transfer pengetahuan faktor penerima pengetahuan merupakan hal yang sangat penting. Kemauan untuk menerima dan mendapatkan pengetahuan dari pengirim ke penerima pengetahuan. Faktor-faktor tersebut yaitu: (a) niat dan kemauan belajar, dalam proses transfer pengetahuan, niat dan kemauan belajar merupakan hal yang sangat penting; (b) sistem penghargaan, suatu organisasi biasanya memberikan penghargaan untuk yang melakukan transfer pengetahuan agar kualitas anggota berkembang dan menambah pengetahuan baru bagi para anggotanya; (c) kemampuan menyerap pengetahuan, niat dan kemauan untuk belajar juga harus diiringi dengan terserapnya pengetahuan baru yang telah dimiliki.

3) Faktor hubungan. Hubungan faktor pengirim pengetahuan dengan penerima pengetahuan terjadi karena adanya interaksi dan relasi diantara keduanya. Faktor hubungan ini dipengaruhi oleh beberapa hal, yakni sebagai berikut.

(a) kolaborasi, kolaborasi dalam transfer pengetahuan memerlukan adanya kemauan dan keinginan antara pengirim dan penerima pengetahuan untuk saling berbagi pengetahuan;

(b) pemilihan kolaborasi, transfer pengetahuan memerlukan keinginan individu maupun kelompok untuk berkolaborasi dalam mentransfer pengetahuan.

(c) sesuai dengan budaya, budaya diartikan untuk berbagi kepercayaan, nilai, dan kebiasaan dalam sekelompok orang maupun komunitas budaya. 
(d) interaksi pengirim dan penerima, dalam berkolaborasi berarti menggabungkan kegiatan antara dua atau lebih perusahaan maupun organisasi untuk mentransfer pengetahuannya.

(e) kepercayaan, percaya adalah salah satu yang paling penting dalam suksesnya hubungan antara organisasi.

(f) keterbukaan, merupakan hal yang harus ada dalam proses transfer pengetahuan.

(g) menghormati dan menghargai, merupakan hal penting antara pengirim dan penerima pengetahuan;

(h) pemecahan masalah, individu diharuskan untuk berbagi ide dalam memecahkan masalah dengan membentuk kolaborasi atau kerjasama dalam transfer pengetahuan.

(i) media, pemilihan media untuk komunikasi yang tepat sangat berpengaruh dalam proses transfer pengetahuan.

Tobing (2007), menjelaskan proses konversi pengetahuan tasit dan eksplisit melalui proses SECI (Gambar 1) yang disampaikan oleh Nonaka dan Takeuchi yaitu sosialisasi, yang merupakan proses berbagi dan penciptaan pengetahuan tasit melalui interaksi dan pengalaman langsung. Kegiatan ini memperlihatkan bahwa pentingnya pengetahuan bersama dan transfer pengetahuan.

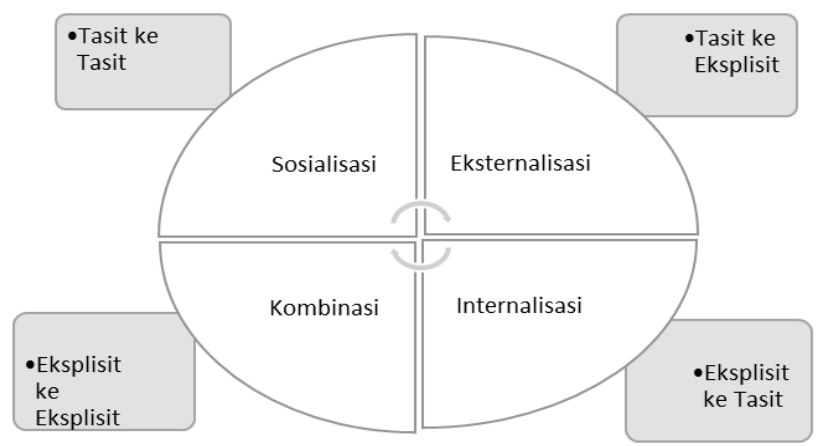

Gambar 2.1 Teori SECI (Tobing, 2007)

Sosialisasi bersifat berbagi, mengkoordinasi, menyebarkan suatu informasi yang menjadikan pengetahuan bersama. Eksternalisasi, merupakan pengartikulasian pengetahuan tasit menjadi pengetahuan eksplisit melalui proses dialog dan refleksi untuk melestarikan dan memudahkan proses menerima pengetahuan. Kombinasi, merupakan proses konversi pengetahuan eksplisit menjadi pengetahuan eksplisit yang baru melalui sistemisasi dan pengaplikasian pengetahuan eksplisit, berupa kombinasi dari sebuah buku, tugas, percakapan telepon, maupun komunikasi melalui jaringan internet. Kemudian diolah, dan disortir menjadi sebuah pengetahuan baru. Internalisasi, merupakan proses pembelajaran dan akuisisi pengetahuan yang dilakukan oleh anggota organisasi terhadap pengetahuan eksplisit yang disebarkan ke seluruh organisasi melalui pengalaman sendiri sehingga menjadi pengetahuan tasit anggota organisasi.

\subsection{Tunanetra}

Tunanetra berasal dari kata "tuna" yang artinya rusak atau cacat dan kata "netra" adalah mata atau penglihatan, jadi tunanetra adalah rusak dalam indra penglihatan. Pengertian tunanetra tidak saja mereka yang buta, tetapi mencakup mereka yang mampu melihat tetapi terbatas, seperti low vision atau rabun merupakan bagian dari tunanetra. Pada dasarnya penyandang tunanetra memiliki intelegensi yang normal dan tidak ada gangguan. Hambatannya adalah keterbatasan dalam indra penglihatan (Akbar, 2011). Berdasarkan kemampuan daya penglihatan, Direktorat Sekolah Luar Biasa membagi tunanetra menjadi beberapa bagian, yaitu: 
1) Tunanetra ringan (defective vision/low vision), mereka yang memiliki hambatan dalam penglihatan akan tetapi mereka masih dapat mengikuti program-program pendidikan dan mampu melakukan pekerjaan/kegiatan yang menggunakan fungsi penglihatan.

2) Tunanetra setengah berat (partially sighted), mereka yang kehilangan sebagian daya penglihatannya.

3) Tunanetra berat (totally blind), mereka yang sama sekali tidak dapat melihat. Perbedaan kondisi anak tunanetra baik dari segi waktu terjadinya ketunanetraan ataupun dari segi kemampuan daya penglihatannya menyebabkan adanya perbedaan kemampuan, sikap dan tingkah laku anak tunanetra tersebut, baik dalam kehidupan sehari-hari ataupun dalam beraktivitas di sekolah, sehingga diperlukan suatu perhatian khusus dalam proses belajar mengajar.

Dalam pembelajaran untuk tunanetra juga harus memakai media pembelajaran. Media pembelajaran ini meliputi alat secara fisik dapat digunakan dalam menyampaikan materi pembelajaran yang terdiri dari talking book, tape recorder, kaset, video, komputer bicara, braille kit, dan sebagainya. Media ini berfungsi sebagai sarana dalam komunikasi belajar mengajar yang menggunakan perangkat keras maupun lunak yang digunakan untuk mencapai tujuan dalam pembelajaran yang efektif dan efisien. Para ahli mengatakan bahwa tunanetra dalam pembelajarannyapun diperluas. Awalnya hanya ada seperti bahasa, seni, matematika, dan sebagainya, kemudian diperluas menjadi keterampilan kompensatoris, keterampilan interaksi sosial, dan keterampilan pendidikan karir. Keterampilan tersebut akan berhubungan langsung dengan pengalaman dan keterampilan hidup (Munir \& Saeful, 2016).

\section{METODE}

Dalam penelitian ini menggunakan pendekatan kualitatif. Dalam penelitian ini dimaksudkan untuk memberikan gambaran mengenai secara seksama mengenai proses transfer pengetahuan pengajar tunanetra di Yayasan Mitra Netra. Penelitian ini menggunakan metode studi kasus. Menurut Cresswell (2010) studi kasus adalah suatu model yang menekankan pada eksplorasi dari suatu sistem yang terbatas pada satu kasus atau beberapa kasus secara mendetail disertai dengan penggalian data secara mendalam yang melibatkan beragam sumber informasi yang kaya akan konteks. Studi kasus ditandai dengan peneliti menghabiskan waktu cukup lama di suatu tempat dengan secara personal dengan kegiatan dan kasus-kasus yang terjadi, merefleksikan, dan membenarkan makna dari hal-hal tersebut. Penelitian ini dilakukan dimulai dari bulan Maret sampai dengan bulan Mei 2019.

Penelitian ini dilakukan di Yayasan Mitra Netra. Informan dalam penelitian ini adalah pengajar dan murid di Yayasan Mitra Netra. Dalam pemilihan informan peneliti menggunakan purposive sampling. Kriteria untuk informan pengajar yaitu penyandang tunanetra, menjadi seorang pengajar senior, dan merupakan pengajar dalam bagian pendidikan dan pelatihan, sedangkan untuk murid yaitu penyandang tunanetra, merupakan murid dewasa, mempersiapkan diri ke jenjang universitas dan bekerja, dan juga tunanetra dengan berkebutuhan plus. Adapun Informan (Tabel 1) yang telah dipilih berjumlah delapan orang, terdiri dari empat pengajar yaitu pengajar penyandang tunanetra totally blind dan low vision dan empat orang murid.

Tabel 1. Tabel Informan

\begin{tabular}{|l|l|l|}
\hline \multicolumn{1}{|c|}{ Nama } & \multicolumn{1}{c|}{ Pengajar } & \multicolumn{1}{c|}{ Tunanetra } \\
\hline Adi & Huruf Braille & low vision \\
\hline Irma & Bahasa Inggris & totally blind \\
\hline Giyo & Komputer dan Programming & totally blind \\
\hline Suryo & Komputer & low vision \\
\hline
\end{tabular}




\begin{tabular}{|l|l|l|}
\hline Taufik & Murid & low vision \\
\hline Maemun & Murid & totally blind, slow learner \\
\hline Putri & Murid & totally blind \\
\hline Ririn & Murid & low vision \\
\hline
\end{tabular}

Dalam penelitian ini dilakukan beberapa tahap pengumpulan data dalam studi kasus yaitu wawancara, observasi, dan analisis dokumen. Adapun pertanyaan besar dalam penelitian ini yaitu proses transfer pengetahuan pengajar tunanetra di Yayasan Mitra Netra dan juga hambatan dalam proses transfer pengetahuan pengajar tunanetra di Yayasan Mitra Netra. Adapun dokumen yang digunakan dalam penelitian ini adalah buku panduan, grup dalam sosial media (WhatsApp/Line), dan video dokumentasi.

\section{HASIL DAN PEMBAHASAN \\ 4.1 Profil Organisasi}

Yayasan Mitra Netra merupakan lembaga informal sebagai tempat belajar dan pelatihan untuk penyandang tunanetra. Yayasan Mitra Netra berdiri 14 Mei 1981 di Jakarta. Yayasan Mitra Netra berfokus pada kegiatan di bidang pendidikan dan lapangan kerja, khususnya bagi penyandang tunanetra. Dalam bidang pendidikan, Yayasan Mitra Netra memiliki beberapa layanan seperti komputer, huruf braille, dan bahasa inggris (Yayasan Mitra Netra, 2019). Di Yayasan Mitra Netra, murid diajarkan oleh para pengajar yang sebagian adalah seorang penyandang tunanetra juga. Transfer pengetahuan dalam dunia pengajaran antara pengajar dan murid untuk mengembangkan pengetahuan dan keterampilan yang mereka miliki. Murid yang belajar di Yayasan Mitra Netra didominasi oleh murid dewasa. Pembelajaran kepada murid yang dewasa biasanya lebih luas dibandingkan murid usia lainnya karena murid dewasa diharuskan memiliki keterampilan untuk sebagai bekal mereka ke jenjang universitas maupun dalam pekerjaannya.

\subsection{Profil Informan}

Adapun deskripsi informan dalam pembahasan proses transfer pengetahuan pengajar tunanetra di Yayasan Mitra Netra. Informan yang dideskripsikan memiliki kualifikasi sebagai informan kunci terkait penelitian. Informan kunci dalam penelitian ini adalah pengajar. Pengajar terdiri dari pengajar huruf braille, bahasa inggris, dan komputer. Ia merupakan pengajar huruf braille dan keyboard di Yayasan Mitra Netra. Ia berlatar pendidikan sarjana bimbingan konseling, dan telah mengajar selama 11 tahun. Sebelum menjadi pengajar, Informan Adi merupakan murid di Yayasan Mitra Netra sejak masih duduk di sekolah SMP. Ia terkenal dikalangan murid-murid karena memiliki pribadi yang asik, dan disenangi oleh murid-muridnya karena mengajarnya yang santai dan sambil bercerita tentang pengalaman.

Informan Irma merupakan pengajar bahasa inggris. Informan Irma merupakan magister di suatu univertas Amerika, dan penyandang tunanetra total (totally blind). Ia sudah mengajar selama 10 tahun. Dulunya, ia juga sebagai murid di Yayasan Mitra Netra. Informan Irma terkenal tegas dalam mengajar. Informan Irma juga sering sekali membaur dan mengobrol bersama dengan murid lainnya ketika jam mengajar telah selesai.

Informan Giyo sebagai pengajar komputer, yang juga tunanetra total (totally blind). Sebelum menjadi pengajar komputer, ia juga murid di Yayasan Mitra Netra. Setelah itu, ia diberikan pelatihan ke Bangkok tentang komputer dan programming untuk tunanetra dan dijadikan pengajar komputer dan programming. Informan Giyo saat ini sedang menjalani kuliah di Universitas Pamulang Jurusan Ilmu Komputer. Beliau sudah mengajar komputer dan programming selama 19 tahun. Ia juga terkenal di kalangan muridnya dengan pribadi yang serius, tegas, dan sangat detail. Selain Informan Giyo, pengajar komputer lainnya adalah Informan Suryo. 
Informan Suryo merupakan pengajar komputer juga tetapi khusus dalam bidang recording. Beliau penyandang tunanetra belum sepenuhnya (low vision). Ia juga sarjana dalam bidang bimbingan konseling. Walaupun begitu, ia sangat menyukai dunia komputer karena pernah belajar di jurusan komputer. Selain itu, Informan Suryo sangat menyukai musik. Sampai saat ini, ia sudah mengajar selama 13 tahun. Ia merupakan client di Yayasan Mitra Netra. Informan Suryo juga disukai oleh para murid karena pribadinya ramah, pendengar, mempunyai jiwa muda, dan suka bercerita dan bertukar pikiran.

Selain pengajar, beberapa murid juga menjadi informan penelitian. Murid yang menjadi informan adalah murid dewasa, yang mengikuti kelas huruf braille, bahasa inggris, dan komputer. Informan Taufik merupakan murid di Yayasan Mitra Netra, yang telah belajar selama lima tahun. Informan Taufik merupakan tunanetra tidak sepenuhnya (low vision). Selain kelas pelajaran umum, Informan taufik juga mengikuti kelas musik karena dia sangat menyukai musik. Saat ini, informan Taufik juga sedang mempersiapkan untuk melanjutkan kuliah. Informan Maemun juga telah menjadi murid selama lima tahun, dan saat ini sedang menyiapkan diri untuk melanjutkan ke jenjang pendidikan yang lebih tinggi. Informan Maemun merupakan tunanetra (low vision) dan juga anak berkebutuhan khusus slow learner. Informan Putri juga murid di Yayasan Mitra Netra, yang sudah belajar selama tiga bulan. Informan Putri merupakan tunanetra sepenuhnya (totally blind). Awalnya, Informan Putri merupakan mahasiswa jurusan Teknik Kimia Universitas Indonesia tetapi keluar karena kampus tidak mengizinkan mahasiswa yang memiliki kekurangan penglihatan. Akhirnya, Informan Putri belajar di Yayasan Mitra Netra sambil mempersiapkan kembali masuk ke pendidikan yang lebih tinggi. Kemudian, Informan Ririn, seorang penyandang tunanetra tidak sepenuhnya (low vision). Saat ini, informan Ririn sedang mempersiapkan diri ke pendidikan yang lebih tinggi dan mempersiapkan diri ke dunia kerja. Informan Ririn sudah menjadi murid di Yayasan Mitra Netra selama tiga bulan.

\subsection{Jenis Pengetahuan}

Berdasarkan hasil penelitian bahwa pengetahuan yang ditransfer di Yayasan Mitra Netra ada berbagai macam, yang dikelompokkan berdasarkan pengetahuan tasit dan eksplisit. Para pengajar di Yayasan Mitra Netra mempunyai pengetahuan yang berbeda-beda. Informan Giyo dan Suryo memiliki dengan pengetahuan tentang komputer dan programming. Informan Irma memiliki pengetahuan bahasa Inggris, dan informan Adi memiliki pengetahuan huruf braille.

Sebagian besar murid di Yayasan Mitra Netra adalah murid dewasa dan membutuhkan pengetahuan yang untuk mengembangkan kompetensi seperti komputer dan programming, bahasa inggris, dan huruf braille. Selain pengetahuan tasit yang ada diri pengajar, mereka juga memberikan pengetahuan eksplisit. Pengetahuan eksplisit adalah pengetahuan yang berada dalam bentuk fisik, seperti buku yang ditulis oleh pengajar seperti buku komputer dan programming maupun buku arasemen musik khusus tunanetra.

Selain pengetahuan umum saja yang ditransfer, juga pengetahuan tentang motivasi dan pandangan hidup. Para murid dewasa ini awalnya merupakan orang normal. Kemudian, mereka menjadi tunanetra karena sakit yang menjadikan mereka tunanetra low vision maupun totally blind ketika mereka dewasa. Hal ini membuat mereka harus beradaptasi dengan keadaan yang sekarang menjadi seorang tunanetra. Awalnya mereka menjadi tertutup, curiga kepada orang lain, bergantung pada orang lain dan juga kurang semangat dalam menjalani hidupnya - mereka akan berpikir hidupnya akan selesai.

Setelah para murid dewasa ini belajar di Yayasan Mitra Netra mereka mendapatkan pengetahuan tentang pandangan hidup. Para pengajar memberikan pengetahuan tidak hanya umum tetapi juga pandangan hidup supaya para murid dewasa memiliki semangat dalam hidupnya untuk terus belajar mengembangkan diri walaupun memiliki kekurangan dalam indera 
penglihatan. Para pengajar biasanya memberikan pengetahuan ini ketika sedang proses belajar mengajar maupun sedang mengobrol. Para pengajar memberikan motivasi dan juga pandangan hidup untuk terus mengembangkan diri.

\subsection{Proses Transfer Pengetahuan}

Proses transfer pengetahuan dalam lembaga pendidikan dilakukan dengan pengajar dan murid. Menurut Alavi \& Leidner (2001), transfer pengetahuan adalah tahapan dalam pengetahuan ditransfer dan ada proses berbagi antar-individu, individu dengan kelompok, kelompok pada kelompok dalam suatu organisasi. Dalam proses ini terjadi kegiatan berdiskusi, seminar, belajar dan pembelajaran, serta bekerja kelompok untuk saling bertukar pengetahuan. Pengajar mentransfer pengetahuannya kepada murid. Transfer pengetahuan dilakukan untuk mengembangkan pengetahuan dan keterampilan mereka. Hal tersebut senada dengan pernyataan Liyanage (2009) bahwa transfer pengetahuan merupakan penyampaian pengetahuan dari satu tempat, orang atau kepemilikan kepada lain. Transfer pengetahuan yang berhasil berarti transfer yang menghasilkan penciptaan yang sukses dan penerapan pengetahuan dalam organisasi.

Menurut Narteh (2008) mengatakan bahwa transfer pengetahuan dapat berjalan dengan baik sesuai faktor dari pengirim dan penerima pengetahuan. Sebagai pengirim pengetahuan harus mempunyai metode yang sesuai dalam mentransferkan pengetahuan. Pengirim juga harus memiliki kemampuan dalam mengajarkan untuk dapat dipahami oleh penerima pengetahuan. Sedangkan penerima pengetahuan harus memiliki niat dan kemauan dalam menyerap pengetahuan yang telah ditransfer oleh pengirim pengetahuan. Hubungan pengirim dan penerima pengetahuan terjadi karena adanya interaksi yang terjalin dari transfer pengetahuan. Hubungan pengirim dan penerima pengetahuan menjadi suatu kolaborasi yang membantu dalam membuat pengetahuan baru dan juga transfer pengetahuan berjalan dengan baik.

Yayasan Mitra Netra merupakan lembaga informal sebagai tempat belajar dan pelatihan untuk penyandang tunanetra. Mereka diajarkan oleh para pengajar yang sebagian adalah seorang penyandang tunanetra juga. Transfer pengetahuan dalam dunia pendidikan antara pengajar dan murid untuk mengembangkan pengetahuan dan keterampilan yang mereka miliki. Para murid dikelompokkan dalam belajar sesuai dengan usia seperti anak-anak, remaja, dan dewasa. Murid yang belajar di Yayasan Mitra Netra di dominasi oleh murid dewasa. Hal tersebut dikarenakan banyak dari mereka yang mengalami kebutaan dari mereka dewasa yang membuat mereka harus belajar kembali. Pembelajaran kepada murid yang dewasa biasanya lebih luas dibandingkan murid usia lainnya karena murid dewasa diharuskan memiliki keterampilan untuk sebagai bekal mereka ke jenjang universitas maupun dalam pekerjaannya. Dalam proses transfer pengetahuan pengajar tunanetra di Yayasan Mitra Netra dilihat melalui proses SECI yaitu sosialisasi, eksternalisasi, kombinasi, dan ineternalisasi.

\section{1) Sosialisasi}

Sosialisasi adalah suatu proses komunikasi dan meningkatkan pengetahuan tasit yang dimiliki seseorang (Hall \& Andriani, 2003). Dalam sosialisasi, ada proses pengetahuan tasit ke tasit, termasuk ide-ide dan keterampilan melalui interaksi langsung, berdialog, diskusi, dan pembelajaran dalam kelas. Pengajar mengajarkan para muridnya dengan secara langsung hadir di kelas. Proses transfer pengetahuan dilakukan di dalam kelas kecil yang hanya berisikan lima murid. Hal ini dilakukan supaya proses transfer pengetahuan berjalan dengan efektif dan juga pengetahuan yang ditransfer dapat diserap dengan baik oleh murid. Jika proses transfer pengetahuan dalam satu kelas melebihi lima murid akan menyulitkan pengajar dalam memantau dan memobilisasi murid. 
Dalam proses transfer pengetahuan, pengetahuan yang ditransfer melihat dari kebutuhan murid sehingga adanya tingkatan pengetahuan. Dalam kelas dewasa, para pengajar biasanya memiliki materi yang lebih kompleks. Hal ini karena murid dewasa memiliki kebutuhan untuk melanjutkan pendidikan ke jenjang perguruan tinggi maupun bekerja di salah satu perusahaan. Sehingga murid dewasa ketika proses transfer pengetahuan diberikan tingkatan pengetahuan yang paling sulit yang memang dikhususkan untuk mempersiapkan mereka untuk ke jenjang perguruan tinggi maupun bekerja.

Proses transfer pengetahuan antar pengajar dan murid dewasa dilakukan dalam dua macam kegiatan yaitu formal dan informal. Kegiatan formal dilakukan ketika para pengajar mengajarkan murid-muridnya di dalam kelas. Para pengajar mentransfer pengetahuannya dengan menjelaskan materinya terlebih dahulu dan kemudian dipraktikkan oleh para muridnya. Setelah itu mereka akan diberikan semacam latihan untuk mengetahui sampai mana mereka mengerti apa yang sudah diajarkan oleh pengajar. Para pengajar memiliki metodenya sendiri dalam mentransfer pengetahuan. Ada yang mentransfer pengetahuan dengan metode konsep, serius, cepat dan tegas, ada juga yang metode eksplorasi, santai, dengan bercerita pengalaman dan bertukar pikiran. Metode yang sesuai akan membuat proses transfer pengetahuan berjalan dengan efektif. Tidak semua metode transfer pengetahuan sama, karena sesuai dengan karakteristik pengirim dan juga penerima maupun kebutuhan dari penerima pengetahuan (murid) seperti metode untuk para murid berkebutuhan khusus plus yang menggunakan metode hafalan. Metode ini dilakukan karena dinilai sesuai walaupun membutuhkan waktu yang lama.

Kegiatan sosialisasi informal di Yayasan Mitra Netra dilakukan dalam berbagai macam kegiatan ada maupun diskusi bulanan. Diskusi bulanan dilakukan setiap bulannya pada hari jumat. Diskusi bulanan ini diadakan oleh komunitas lain yang ingin berdiskusi dengan Yayasan Mitra Netra. Diskusi bulanan ini dihadiri oleh semua warga mitra netra seperti pengajar, murid, maupun karyawan. Diskusi bulanan ini tidak tentu tema atau topiknya karena tergantung pada komunitas yang menyelenggarakannya sehingga tema atau topik berbedabeda setiap bulannya seperti diskusi bulanan tentang kesehatan tubuh yang diselenggarakan oleh Yakult. Dalam diskusi ini dihadiri oleh semua warga Yayasan Mitra Netra yaitu pengajar, murid, dan pengurus. Diskusi bulanan yang diadakan oleh Yakult dibawakan oleh humas Yakult itu sendiri. Dalam diskusi ini, pembicara mentransfer pengetahuan dengan mempresentasikan video. Pembicara memberitahukan secara lisan tentang latar yang ada dalam di video tersebut. Setelah itu, ada sesi tanya jawab yang diikuti oleh semua warga Yayasan Mitra Netra.

Dalam sesi tanya jawab, banyak sekali yang pertanyaan yang ditanyakan kepada pembicara. Pertanyaan-pertanyaaan ini seputar tentang kesehatan dan Yakult. Tidak hanya pertanyaan saja tetapi juga saran supaya Yakult menurunkan kadar kandungan gula yang terdapat di dalam Yakult. Diskusi bulanan bertujuan untuk semua warga Yayasan Mitra Netra mendapatkan pengetahuan yang tidak didapat di dalam Yayasan Mitra Netra. Proses transfer pengetahuan dalam diskusi bulanan dari komunitas-komunitas dengan tema yang sesuai dengan fokus komunitas tersebut sehingga semua warga Yayasan Mitra Netra mendapatkan pengetahuan langsung dari yang memang bergelut dalam pengetahuan tersebut. Seperti Yakult yang membawa tema kesehatan karena Yakult memang merupakan produk kesehatan khususnya usus. Dalam proses transfer pengetahuan ini, para warga Yayasan Mitra Netra mendapatkan Yakult gratis dan juga ilmu tentang Yakult. Selain diskusi bulanan ada juga seminar, kunjungan ke komunitas lain, kunjungan ke kedutaan besar maupun program training. Kegiatan ini dilakukan tidak setiap bulannya. Dalam kegiatan informal tidak 
semuanya dilakukan di Yayasan Mitra Netra. Ada beberapa kegiatan yang diluar Yayasan Mitra Netra seperti kunjungan, seminar, dan program training.

Kedua kegiatan ini menimbulkan suatu hubungan kolaborasi antara pengirim dan penerima pengetahuan. Kolaborasi dalam transfer pengetahuan memerlukan adanya kemauan dan keinginan antara pengirim dan penerima pengetahuan untuk saling berbagi pengetahuan. Kebutuhan maupun keinginan dalam menerima pengetahuan adalah alasan untuk berkolaborasi. Kolaborasi bisa membantu dalam penciptaan pengetahuan baru dengan meningkatkan transfer pengetahuan (Narteh, 2008). Sehingga dengan adanya kolaborasi transfer pengetahuan berjalan dengan efektif.

Proses transfer pengetahuan dalam sosialisasi yang dilakukan oleh pengajar dengan murid dewasa di Yayasan Mitra Netra ialah dengan adanya kegiatan sosialisasi secara formal dan informal. Proses transfer pengetahuan dilakukan karena adanya kolaborasi antara pengirim dan penerima pengetahuan. Dalam proses transfer pengetahuan adanya metode yang diaplikasikan sesuai dengan kebutuhan murid. Metode yang sesuai membuat proses transfer pengetahuan berjalan dengan efektif. Transfer pengetahuan tidak hanya dilakukan di dalam kelas maupun hanya lingkungan Yayasan Mitra Netra saja, tetapi juga didapatkan dari luar kelas atau di luar lingkungan Yayasan Mitra Netra.

\section{2) Eksternalisasi}

Tahap eksternalisasi merupakan proses dimana individu membuat pengetahuan tasit menjadi eksplisit yang dapat diakses oleh orang lain (Byosiere \& Luethge, 2012). Eksternalisasi berbentuk dalam tulisan, dialog, refleksi, laporan, dsb. Di Yayasan Mitra Netra, tahap eksternalisasi berbentuk dalam empat jenis yaitu yang pertama, notulensi ini dibuat agar menjadi bukti telah dilangsungkannya suatu rapat. Notulensi ini ditulis ketika berjalannya rapat yaitu setiap tiga bulan dan enam bulan sekali.

Notulensi ini berisikan isi dari suatu rapat. Nantinya notulensi disebarkan lewat e-mail masing-masing pengajar dan pengurus. Rapat tiga dan enam bulan sekali bidang pendidikan dan para psikologi kumpulkan untuk membicarakan perkembangan murid dari setiap pengajar. Yang kedua yaitu, laporan kerja tahun ini dibuat hanya sekali dalam setahun. Nantinya laporan kerja tahun dilaporkan dan dipertanggungjawabkan dalam rapat kerja tahunan. Dalam laporan kerja tahunan membahas tentang kegiatan selama satu tahun, dan juga rencana dalam satu tahun ke depan.

Laporan kerja tahunan dikirimkan lewat email dan dicetak untuk bukti dari rapat kerja tahun. Dan yang ketiga yaitu, laporan seminar atau program training merupakan suatu bukti pertanggungjawaban bahwa sudah mengikuti seminar maupun program training. Dan yang terakhir adalah esai yang ditulis oleh para murid. Esai ini ditulis berdasarkan materi yang sudah dipelajari selama satu semester. Esai ini dilakukan untuk melihat seberapa jauh mereka mengerti dan juga melihat gaya penulisan.

Proses eksternalisasi transfer pengetahuan yang dilakukan di Yayasan Mitra Netra dalam bentuk notulensi, laporan kerja tahun, laporan seminar atau program training, dan essay murid yang disebarkan melalui media e-mail. Proses eksternalisasi ini dilakukan untuk mengembangkan kompetensi para muridnya.

\section{3) Kombinasi}

Kombinasi adalah proses pengetahuan eksplist menjadi pengetahuan eksplisit yang lebih sistematis, dimana membuat suatu hubungan dalam pengetahuan yang sebelumnya (Schulze \& Hoegl, 2008). Dalam proses kombinasi dilakukan dengan cara menggabungkan, mengkategorikan, dan mensintesis pengetahuan eksplisit yang ada. Pengajar Mitra Netra 
sendiri memiliki buku mereka sendiri. Informan Giyo membuat buku pertama tentang komputer dan programming untuk penyandang tunanetra. Beliau membuat buku panduan tersebut karena di toko buku maupun penerbit yang belum membuat buku untuk penyandang tunanetra. Buku tersebut merupakan hasil dari seminar dan program training yang diikuti oleh beliau. Buku tersebut dijadikan sebagai buku panduan oleh para muridnya. Informan Suryo juga membuat buku tentang arasemen musik atau recording. Informan Suryo berpendapat bahwa buku tentang musik yang khusus untuk tunanetra belum pernah dibuat oleh pemerintah dan penerbit.

Tujuan buku yang dicetak kembali dalam huruf braille agar murid-murid mengerti dan juga memiliki referensi selain buku yang dibuat sendiri, seperti buku tentang Windows, bahasa Inggris, dsb., yang memang sudah diterbitkan lalu dicetak kembali menjadi buku dengan huruf braille. Buku-buku yang dibuat oleh pengajar maupun buku yang dicetak kembali menjadi huruf braille maupun talking book disimpan di perpustakaan. Para murid bisa meminjam buku tersebut dengan menjadi anggota perpustakaan.

Dalam tahap kombinasi ini, tidak adanya proses konversi pengetahuan eksplisit menjadi pengetahuan eksplisit baru yang lebih sistematis. Para murid hanya menuliskan esai murid yang dimana esai tersebut hanya dijadikan sebagai penilaian saja. Dalam hal ini, kombinasi yang berasal dari murid tidak ada dan hanya dari pengajar yang ditulis langsung maupun penerbit yang dicetak kembali dalam huruf braille dan talking book.

Proses kombinasi di Yayasan Mitra Netra dilakukan dengan membuat buku panduan yang ditulis berdasarkan pengetahuan yang didapatkan dari mengikuti seminar maupun program training dan juga dari hobi yang disukai. Tidak hanya itu, para pengajar biasanya mencetak ulang buku menjadi huruf braille dan talking book. Biasanya pengajar mengikuti buku dalam mengajari muridnya. Buku-buku tersebut dijadikan semacam acuan dan juga standar dalam mengajar.

\section{4) Internalisasi}

Tahap internalisasi mengacu pada penciptaan pengetahuan tasit dari pengetahuan eksplisit seperti learning by doing maupun pemahaman dari diskusi maupun membaca. Pada tahap internalisasi ini merupakan proses dari pengetahuan eksplisit menjadi pengetahuan tasit. Dalam tahap ini, semua pengetahuan yang terekam dalam bentuk fisik akan disebarkan agar menjadi pengetahuan baru untuk penerima pengetahuan.

Proses internalisasi yang terjadi antara pengajar dan murid tidak langsung terjadi. Proses internalisasi terjadi dengan perlahan agar pengetahuan yang ditransferkan dapat dicerna dan diresapi ke dalam penerima pengetahuan. Adanya kepercayaan, keterbukaan, maupun saling menghormati dan menghargai satu sama lain menjadikan suatu proses transfer pengetahuan menjadi lebih baik (Narteh, 2008). Hal ini membuat pengetahuan mudah diresap oleh penerima pengetahuan yaitu murid dewasa.

Transfer pengetahuan menjadikan suatu proses transfer pengetahuan seperti yang dirasakan oleh para murid sebagai penerima pengetahuan tentang transfer pengetahuan yang selama ini dilakukan oleh mereka, dan yang dirasakan oleh para murid sebagai penerima pengetahuan tentang transfer pengetahuan yang selama ini dilakukan oleh mereka. Informan Ririn mengatakan bahwa dengan adanya transfer pengetahuan yang dilakukan baik dalam kegiatan formal maupun informal. Awalnya, awalnya informan Ririn adalah low vision yang sekarang telah menjadi totally blind dengan ia belajar di Yayasan Mitra Netra banyak sekali pengetahuan yang diperoleh. Informan Ririn juga mendapatkan motivasi dan cara pandang baru, yang membuat semangat dirinya untuk terus mengembangkan diri. Hal yang sama juga 
dirasakan Informan Taufik, bahwa terjadi banyak perubahan yang ia miliki selama belajar di Yayasan Mitra Netra.

Transfer pengetahuan memiliki banyak manfaat yang dapat meningkatkan pengetahuan dan keterampilan dalam individu. Dari hasil transfer pengetahuan adanya pengetahuan baru untuk mengembangkan kompetensi yang dimiliki. Tidak hanya keterampilan saja tetapi juga motivasi dan cara pandang yang dapat memacu ia untuk lebih bersemangat lagi dalam mengembangkan diri di bidang apapun. Manfaat dari transfer pengetahuan yang sangat dirasakan oleh murid menjadikan mereka terus berkembang.

Hasil transfer pengetahuan sangat berdampak terhadap kompetensi mereka. Informan Adi mengatakan bahwa para murid semakin meningkat kemampuannya setelah ada transfer pengetahuan. Terlebih lagi dengan murid tunanetra yang memiliki kebutuhan khusus slow learner. Pengajar akan merasa kesulitan dengan murid yang slow learner karena cara belajarnya lebih lambat. Informan Maemun selama belajar di Yayasan Mitra Netra memiliki kemampuan yang bagus, meskipun dalam proses yang lama. Selain itu, perilaku informan Maemun juga mengalami perkembangan, misalnya sudah mau berinteraksi dengan temantemannya di Yayasan Mitra Netra. Ia juga berani berangkat ke Yayasan Mitra Netra menggunakan angkutan umum.

Proses internalisasi dari transfer pengetahuan antara pengajar dan murid untuk mengembangkan kompetensi mereka, sehingga mampu mempersiapkan diri ke jenjang pendidikan yang lebih tinggi ataupun bekerja. Proses internalisasi ini membutuhkan proses dan waktu yang cukup panjang karena mengubah dan membentuk perilaku, cara pandang, dan keterampilan para murid.

\subsection{Hambatan Proses Transfer Pengetahuan di Yayasan Mitra Netra}

Hambatan yang terjadi dalam transfer pengetahuan dapat menyebabkan pengetahuan yang ditransferkan tidak dapat diterima dengan baik maupun tidak adanya proses transfer pengetahuan. Transfer pengetahuan dalam kelas antara pengajar dengan murid. Dalam mentransfer pengetahuan diperlukan komunikasi yang baik agar transfer pengetahuan berjalan dengan efektif dan efisien. Dalam transfer pengetahuan, pengirim dan penerima pengetahuan sangatlah berpengaruh. Pengirim pengetahuan harus memiliki kemauan dalam mentransferkan pengetahuan yang dimilikinya. Begitu pula dengan penerima pengetahuan yang juga harus memiliki niat dan kemauan dalam menyerap pengetahuan yang telah ditransfer oleh pengirim pengetahuan (Narteh,2008).

Hambatan yang terjadi dalam proses transfer pengetahuan yaitu sifat malas murid. Menurut Narteh (2008), bahwa proses transfer pengetahuan terjadi karena adanya kolaborasi antara individu dengan individu. Kolaborasi terbentuk karena adanya keinginan dan kebutuhan yang sama. Adanya keinginan dari penerima pengetahuan untuk menyerap pengetahuan yang ditransferkan membuat pengetahuan terserap. Sifat malas yang terkadang tidak masuk kelas membuat berkurangnya kegiatan transfer pengetahuan. Sifat malas dari murid biasanya karena cuaca yang tidak mendukung maupun tidak adanya keinginan untuk belajar. Faktor ini juga terkadang dari orang tua murid tersebut yang kurang memperhatikan untuk selalu memberikan motivasi kepada muridnya.

Hambatan kedua adalah suasana perasaan seseorang. Suasana perasaan seseorang merupakan hal yang sangat penting untuk diperhatikan. Bila suasana hati seseorang sedang tidak baik maka proses transfer pengetahuan berjalan tidak efektif. Bila suasana hati sedang tidak enak karena adanya suatu masalah yang lain dapat menghambat berjalannya transfer pengetahuan. Proses transfer pengetahuan terjadi karena adanya kolaborasi antara pengirim dan penerima pengetahuan. Berkolaborasi berarti menggabungkan dua atau lebih individu maupun organisasi 
untuk mentransfer pengetahuannya. Pasti memiliki banyak perbedaan dalam banyak hal, seperti sifat, perilaku, norma dan nilai, maupun tujuan (Narteh, 2008). Kolaborasi akan terganggu ketika pengirim maupun penerima memiliki perbedaan sikap yang sangat terlihat seperti suasana hati yang tidak baik akan membuat proses transfer pengetahuan berjalan dengan tidak efektif. Suasana perasaan sesorang yang sedang tidak baik membuat tahap sosialisasi menjadi terhambat. Terlebih lagi bila pengirim pengetahuan yang memiliki suasana hati yang sedang tidak baik menimbulkan transfer pengetahuan yang tidak baik dan efektif. Penerima pengetahuan akan timbul tidak nyaman selama berjalannya proses transfer pengetahuan.

Hambatan ketiga adalah penjelasan yang terlalu cepat. Dalam proses transfer pengetahuan penjelasan yang terlalu cepat bisa membuat pengetahuan tidak terserap dengan baik. Pengetahuan yang diserap oleh penerima pengetahuan tidak sepenuhnya karena penjelasan yang terlalu cepat. Menjelaskan terlalu cepat merupakan metode yang kurang tepat karena setiap murid memiliki kemampuan yang berbeda-beda. Metode yang digunakan dalam proses transfer pengetahuan menyesuaikan dengan karakterisktik penerima pengetahuan. Metode yang sesuai akan mempermudah berjalannya proses transfer pengetahuan antara pengirim dan penerima pengetahuan. Kolaborasi yang sudah dibangun antara pengirim dan penerima pengetahuan akan kurang efektif bila menggunakan cara yang salah (Narteh, 2008). Hal ini yang membuat proses transfer pengetahuan menjadi tidak efektif.

Hambatan keempat adalag proses transfer pengetahuan pada murid tunanetra yang berkebutuhan khusus plus. Berkebutuhan khusus plus termasuk autis, slow learner, atau keterbelakangan mental. Hambatan yang terjadi karena sebelumnya Yayasan Mitra Netra hanya menerima murid dengan tunanetra murni atau yang merupakan hanya memiliki keterbatasan mental saja tanpa adanya kekurangan terlebih lagi, namun sekarang juga menerima murid tunanetra yang berkebutuhan khusus plus. Para pengajar mengalami kewalahan dalam mengajarkan murid tunanetra dengan berkebutuhan khusus pnglus. Dalam hal ini, Metode transfer pengetahuan yang digunakan menyesuaikan dengan lingkungan mereka berada. Tidak hanya itu kemampuan untuk mengajari merupakan hal terpenting untuk pengirim pengetahuan. Semakin memiliki pengalaman dalam mentransfer pengetahuan akan lebih mudah untuk mentransfer pengetahuan ke individu maupun kelompok lainnya sebagai penerima pengetahuan (Narteh, 2008). Para pengajar melakukan proses transfer pengetahuan dengan murid berkebutuhan khusus plus dengan metode hafalan dan waktu dalam proses transfer pengetahuan juga lebih pendek yaitu hanya 30 menit.

\section{KESIMPULAN}

Kegiatan transfer pengetahuan antara pengajar dan murid di Yayasan Mitra Netra masih perlu dikembangkan. Pengajar sebagai pengirim pengetahuan yang mentransferkan pengetahuan mereka kepada penerima pengetahuan yaitu murid dewasa. Transfer pengetahuan pengajar tunanetra di Yayasan Mitra Netra mengacu SECI menunjukkan bahwa sosialisasi merupakan kegiatan paling dominan dibandingkan tahap lainnya. Sedangkan dalam tahap eksternalisasi, kombinasi, dan internalisasi lemah dibandingkan sosialisasi karena bentuk pengetahuan eksplisit murid masih perlu dikembangkan. Dalam ketiga tahap tersebut hanyalah pengetahuan eksplisit dari para pengajar dan hasil tulisan murid hanya sebagai penilaian saja dan perlu adanya perkembangan untuk pengaplikasiannya yang membuat murid sebagai penerima mendapatkan pengetahuan baru. Hambatan yang terjadi dalam proses transfer pengetahuan di Yayasan Mitra Netra yaitu sifat malas murid, suasana perasaan seseorang, mengajar terlalu cepat, dan tunanetra dengan berkebutuhan khusus seperti slow learner. 


\section{DAFTAR PUSTAKA}

Akbar, R. 2019. Pengertian Tunanetra. http://kartunet.com/pengertin-tunanetra-656.htm (akses 15 Desember 2019).

Alavi, M. \& Leidner, D. 2001. Review Knowledge Management and Knowledge Management Systems: Conceptual Foundations and Research Issues. MIS Quarterly, 25(1), 36-107.

Awad, E. \& Ghaziri, H. 2010. Knowledge Management, Second Edition. Virginia: An International Technology Group, LTD.

Bou-Llusar, J. C. \& Segarra-Cipres, M. 2006. Strategic Knowledge Transfer and Its Application for Competitive Advantage: An Integrative Conceptual Framework. Journal of Knowledge Management, 10(4), 100-112.

Byosiere, P. \& Luethge, D. 2012. Knowledge Domains and Knowledge Conversion: An Empirical Investigation. Journal of Knowledge Management, 12(2), 67-68.

Cabrera-Suarez, K., et.al. 2001. The Succesion Process from a Resource and Knowledge Based View of The Family Firm. Family Bussiness Review, 14-37.

Chandra, S. 2015. Pemanfaatan Media untuk Tunanetra di Jakarta: Sebuah Studi Tentang Pemanfaatan Media oleh Anggota Perpustakaan Yayasan Mitra Netra. Skripsi. Depok: Universitas Indonesia.

Cresswell, J.W. 2010. Qualitative Inquiry and Research Design: Choosing among Five Approach. University of Nebraska: Sage Publication.

Greiner, M.E., et.al. 2007. A Strategy for Knowledge Management. Journal of Knowledge Management, 11(6), 3-15.

Hall, R. \& Andriani, P. 2003. Managing Knowledge Associated With Innovation. Journal of Bussiness Research, 56(2), 145-152.

Jasimuddin, S.M., et.al. 2014. A Decision Tree Conceptualization of Choice of Knowledge Transfer Mechanism: The Views of Software Development Specialists in A Multinational Company. Journal of Knowledge Management, 18(1), 194-215.

Kumar, J. \& Ganesh, L. 2009. Research on Knowledge Transfer in Organizations: A Morphology. Journal of Knowledge Management, 13(4), 161-174.

Laksmi, L., Wijayanti, L. \& Fauziah, K. 2016. Local Wisdom-Based Strategy of Transfering Knowledge among Educators at Early Chilhood Education Programs in Sreseng Sawah Subdistrict, Jagakarsa District. International Review of Humanities Studies, 1(2), 180-202.

Liyanage, C., et.al. 2009. Knowledge Communication and Translation: A Knowledge Transfer Model. Journal of Knowledge Management, 13(3), 118-131.

Munir, E.S. \& Sensus, A.I. 2016. Modul Guru Pembelajaran SLB Tunanetra Kelompok Kompetensi G: Komunikasi Efektif. Jakarta: Kementerian Pendidikan dan Kebudayaan.

Narteh, B. 2008. Knowledge Transfer in Develop-Developing Country Interfirm Collaborations: A Conceptual Framework. Journal of Knowledge Management, 12(1),78-91.

Schulze, A. \& Hoegl, M. 2008. Organizational Knowledge Creation and The Generation of New Product Ideas: A Behavioral Approach. Research Policy, 37(10), 1742-1750.

Tobing, P.L. 2007. Knowledge Management: Konsep, Arsitektur, dan Implementasi. Yogyakarta: Graha Ilmu. 
BACA: Jurnal Dokumentasi dan Informasi, 42 (2) Desember 2020, Halaman: 227-242

Warnar, P. 2012. Family Business and Knowledge Transfer: How to Survive to The Next Generation. Netherland: Delft University of Technology.

Yayasan-Mitra-Netra, Y. 2019. Profil Yayasan Mitra Netra. Di https://mitranetra.or.id/profil ((akses 15 Januari 2020). 